\title{
Bio politics and Historical Resilience of Neoliberalism in the Wasted Vigil and Red
}

\section{Birds}

\author{
* Sajida Ahmad Ali, PhD Scholar (Corresponding Author) \\ ** Dr. Muhammad Asif, Assistant Professor
}

\begin{abstract}
The proposed paper aims to explore the biopolitical constructed neoliberal schema of political economy that formalizes non-economic issues into economical monetarism of the socialization through its contingent nature. The biopolitics functions as an agent to govern the neoliberal resilience in the Muslim Nation-States in the shade of neo-colonial shapes. The neoliberal resilience through the capacity of biopolitics to control and command the biopower has interchanged the relationships of the social phenomena to economic activism. The neo trends of Globalization through hype real celebrated stigma of inclusion, exclusively, forcing the pure socially developed phenomena as; cultures, nationalist ethnicity, indigenousness, localism, wars and militarism, resistance, environment, psychology, sovereignty, and security of states, into neoliberal political economy. The paper will serve Foucauldian biopolitics, as it adapts a partial perspective. In one way, it is a complementary power to govern and in the other way, biopolitical rationalities to govern over the crises and recessionary risks stem from the neo-liberalization of the entire phenomena of social life via resilient forces. This privatization of economic financialization of material profit is at the cost of loss of socialization in every field of life that proves a resilience or restoration of the liberal doxa into revision. This paper will explore the possibility of biopolitical-established governance of neoliberal resilience through the textual biopolitical critique of the economization of socialization from The Red Birds by Mohammed Hanif and The Wasted Vigil by Nadeem Aslam. These novels reflect on the resilient nature of neoliberal trends and the havoc caused by its neo forms through its power of adaptability and capacity to change in the nation-states.
\end{abstract}

Keywords: Biopolitics, Biopower, Neoliberal Resilience, Globalization, American Globalization, Political Economy

\section{Introduction}

This paper will explore the adaptable nature and a precedent resilience of neoliberal practices backed by biopolitics. This research will present a critique of the biopolitical, settled neoliberal ideology of economization and the financialization of the social phenomena of life. Neoliberalism has survived after the global crisis through biopolitically established government rationales to control the biopower that faces a constant contact with the danger of loss of socioeconomic activities and opportunities. The novels, The Wasted Vigil (2008) and Red Birds (2018) reflect on the power of adept ability of the neoliberal doxa of capitalism. Both the novels respond to the biopolitical control of Muslim NationStates through the resilient nature of neoliberal ideology, constructed by capitalism. These novels elaborate on the impacts of external neoliberal interventionism on the Muslim states and their results that how the biopower suffers through the economization of the socialization, in the name of inclusion of globalization as propagated by Eurocentric mainstream empirical states. Biopolitics is the politics of controlling and governing the biopower through interventions of state-oriented rationale structures. The various scholars have used the term in prolific ways; hence, Foucault defines the term in Birth of Biopolitics as a relation of politics and life as governed by the state rationale. He states it as an "art of government" (1979, p. 2) that works in multiple shades and confirms its resilient nature (see Excerpt 1 in Appendix 1 for further details). Moreover, Nancy Fraser offers the assumption that today a" Global Government" is governing the world; a government above the nation-states (Kelly, 2008, p.3)

* Department of English Literature, Government College University, Faisalabad, Pakistan. Email: dauedahmad4@gmail.com

** Department of English Literature, Government College University, Faisalabad, Pakistan. Email: muhammadasif@gmail.com 
but (Kiersey, 2009, p.36) a point out that neoliberalism is the main rationale of today as Foucault also suggests that neoliberalism through its resilient nature has acquired an international power over the nation- states forced by biopolitics. The adaptability of neoliberal resilience instigates a culture of private corporations which dominates the social activism and public life so that the state becomes an agent to work for neoliberal doxa of more profits (Crouch, C. 2011, p.23). The paper serves the effects of neoliberal resilient in the Muslim- Nations States as "compression of morbidity on population" (Dillon, Guerrero, L. 2008, p.1) through heterogeneous diversions of liberal doxa and the both of the novels reflect on the existing realities minutely.

\section{Define the Problem}

This research offers a biopolitically constructed resilience of neoliberalism with a strong power of adaptability into prolific shades. The function of neoliberalism to the economization of the noneconomic social phenomena has a revision of biopolitics as a biopolitical turn that re-establishes the neoliberal structures even after crises and spaceoutemporal changes.

\section{Research Methodology}

The research methodology for this paper will be qualitative. This research paper will present a biopolitical critique of the resilience of the neoliberal economization of the non-economic social phenomena in the Muslim Nation-states, portrayed in The Wasted Vigil (2008) and Red Birds (2018). The biopolitical critique will be presenting through textual analysis of the above-mentioned novels.

\section{Discussion}

Foucault's often apparent abandonment of the project he outlined in his magnum La volonté de savoir takes place under conditions identified and defined by the rise of power of neoliberal theories and practices in Deng Xiaoping's China, Thatcher's England and in America during Ronald Reagan's era, who is the resource person of neoliberal policies and its adaptability into resilient power, offers a complex relationship of theory and its practice in every day economical, and social reality in Muslim nation-states.

Foucault's concept further is expanded by Agamben's idea of biopower. He proposes that the population responds to the call of state and Foucault's idea is how the government controls the will of the bare life by involving political intelligentsia. The Agambean (1998) concept of biopower is essential for the understanding of the relationships of Biopolitics and neoliberal resilience as it is always biopower (bare life) that is at the core of dangers of revisionary resilient neoliberal schemas. Neoliberalism, an ideology of the Lassie fair (free economy) that has promoted free economic functions and a popular assumption of freedom and liberty, under the umbrella of politics of Globalization and economization of social phenomena; man as liberal being (see Excerpt 2). Moreover, it devotes a secondary significance (see Excerpt 3). Liberalism definite is a unique identity that ever keeps on transcendental values, having vast internal varieties and complexity of meanings. Classical liberalism has always been functioned in a changing framework, from classical to its journey of popular social democratic adaptability today in nation-states. The textual response of The Wasted Vigil (2008) reflects on the historical associations of the Afghani humans with the government rationale of controlling power of the world-empires since the pre-Islamic age, and further the Britain Empire, Russian and American intruders who subjected the population (see Excerpt 4).

The Russian and American empires till the present day, since mercantilism to physiocracy and then, free economic age, robbed the land and its peace. The tale of liberalism is full of serfdom that functions to serve the empires to get them rich. As, Lara, the protagonist, in The Wasted Vigil(2008), searches the painted walls of the house where she lives with Marcus, she reminds of the destiny of the land to the reader as (see Excerpt 5) a tale of Foucauldian external limitless intrusions into the distant land of Afghanistan. The novel weaves the web of the population of Afghanistan which is controlled by the external liberalists and neoliberalists, to prove the hegemony over the biopower as Foucault states in Right of Death and Power Over Life in which he argues about the gambling of staking of life of the others as designed wholesomely, nuclear annihilation as Misses a pro-economic non- interventionist, anti-imperialist, referred to modern wars and its advancements (see Except 6). The neoliberal military led economization is a threat and survival strategy (see Excerpt 7)Red Birds (2018) depicts the Afghani population under the permanent threat of bombing or air attacks but for the capitalist, this is a power and strategy for survival. The neoliberal resilient nature has come to the extreme of individualism that forgets that how to survive collectively because "there is no longer any outside left to view, let alone to stand on" (Foucault, 1979, p.17). In Society Must Be 
Defended Foucault's biopolitical perspective appears homologous to thantopolitics that the life and its components of a specific "self- identified race" of human beings become the target of exclusion of the other stigmatized as inferior "race from life itself"'(Foucault, 1976, p. 46). The racism we experience in the biopolitical field that is an emphasis on fixed and immutable "cultural differences" of "master race" is proper to laissez-faire capitalist economy, a racism that explains why the unequal distribution of biopower, the distribution of resources of globalized capitalism into such "life zones" where crucially, the citizenry is equally guarded by the danger of host of advanced techniques of better health, life's security, and its safety, and at the same time "death zones" were denied "wasted lives" face an exposure to death, disease, sudden calamities in the form of accidents of explosions, and imposed external wars, left the mass to die (Bablibar, 2004, p. 126) and could not be otherwise. The post and pre 9/11 Afghanistan was taken as an exclusive Muslim fundamental territory represented by Eurocentric media, literature, and think-tanks (see Excerpt 8). Foucault's biopolitics exposes constitutively appropriate a Reaganite form of Keynesian control where "government is not the solution to our problems, but the problem itself." (Campbell and Sitze, 2013, p. 21).As this Keynesian doxa worked for invasions of Iraq and Afghanistan after 11 September 2001, the war on terror by USA military in simple terms is - "return of the empire"(Tariq Ali,2003,p. 1-19).Thirty years earlier, Arendt had studied a similar aporia of politics referring to refugee crisis that emerged in the wake of the Second World War, he inquired into the aporia of human rights of - stateless people\| who had been excluded from legal protection except those of human rights as in The Wasted Vigil the Afghani refugees in Peshawar, Pakistan lead a life of extreme poverty as stateless biopower which is identified biopolitically. In 1951, a year almost after the Universal Declaration of Human Right (1948), Arendt reflects on The Perplexities of the Rights of Man (1789) on insoluble impasse to the Declaration that "stateless people" were most in need of the protections of human rights. Moreover, it is the dogma of neoliberal politics of exclusion and its resilient features that no right can be imposed outside of the established political community, that is why human rights were all but meaningless for the mass who no longer were supposed to belong to any political community and face a biopolitical racism of the states, this is the most miserable case of economization of social well being of suffering humanity, empowered by monetarism. Moreover, political meant any politically established territory or ethnic group, this political phenomena, in turn, gave rise to the aporia that provoked Arendt's thought as - pure humans\| as humans in general, rather than as members of this or that particular political community, as -English\| or -Frenchl. The stateless mass is a community of humanity denied of -rights of manl among humanity when war mass migration takes place; ultimately the Muslim world is suffering from a horrible refugee crisis in Asia. The human rights analyzed by Arendt and Foucault were declared at the precise moment when law and its legislative bodies lost touch with life however the aims benefits universalism and its exclusive ideology, which benefits the rich and capitalists only. In the thinking of both Foucault and Arendt, it is a paradox that law itself protects anti-human neoliberal legislation that inclusion of life within law" shadows the coincides with the "the exclusion of life from lawl (Campbell and Sitze, 2013, p. 24). Red Birds(2008) portrays the Afghani refugees and The Wasted Vigil shows the Afghanis into Peshawar, Pakistan, a population that is victim of international emirs' economization of the wars and their brutal actions of denial of human rights. The novel explores the assaults of the externals to intrude into the Muslim territory as lives of the population are biopolitically controlled as, the humans cannot put the question of security of life to the government rationalities that two million deaths over the past quarter century happened in Muslim world.\|(Aslam, 2008, p. 14) by conversion of the roles of human social actions and economic designs with one another or into one measurement and it is a quite different stance of the liberal ideology of the Eurocentric mainstream that idealizes individual's liberty. However, at the same time taking the lives of Muslim biopower (see Excerpt 9). The texts of both novels reflect on the historical imperial programs staged by the empires of the world as the Great Game of the world that the characters are stunned and baffled by the contacts of too many wars of the global empires (see Excerpt 10). Lara opens the book and looks at the lines (see Excerpt 11) that justify the subjectification of the biopower and the destruction by the actions of intrusions.

Moreover, biopolitics proves a slippery term that strengths the neoliberal resilience as often becomes potentially dangerous as it may butcher or - persecutes some in the name of $\|$ a greater good or greater loss and in this respect it may act as - audacious gambitsll which creates macabre effects in the lives of biopower\| (G.E. Kelly, 2004,p.18). During the classical period of liberalism, the 
indigenous were butchered through free exchange of physiocracy and mercantilism, by the hands of Great Britain who injected a long history of colonization of one-third of the globe, by settling in the distant lands and also in Afghanistan, Pakistan, Iran and Iraq. The novel The wasted Vigil portrays the historical massacre of Qissa Khwani bazaar in Peshawar, Pakistan, the draconian clutches of the liberals as given in Excerpt 12.

Britain - colonization ended and liberalism took another birth as the neo ideas and methodologies were applied to loot the world by the whites of America and its industrialists and proprietors by bringing the Keynesian's model of monitoring the wealth of the nations under the umbrella of American Globalization. Historically, the relativity of biopolitics and neoliberalism works as a way forward for the crisis categorically faced by Euro Americans as the Great Depression(1929) and global financial crisis 2007/2008 that raised the presumption of an end of liberal and neoliberalism. It was assumed that after the crisis of free economic mode, there would be an expected "post-neoliberal regime" (Konings, 2016, 268: see also Crouch, 2011; Dean, 2014; Harvey, 2011; Peck, 2010; Peck et al., 2010; Schmidt and Thatcher, 2013) but conduction of control of biopolitics became the source of survival of neoliberalism and its hegemonic regulations of Keynesian structural adjustment program. Moreover, biopolitics gives strength to neoliberalism to adapt a dual identity to work for its liberalist global materialistic designs and it proves that it is a slippery term and penetrates all spheres of social life of the Muslim states, with its resilient nature that gives strength to liberal projects of controlling the biopower of the other nations in the names of global projects of crime control or international trade pursuits. Moreover, Keynesian monetarism; government with the aids of the militarization of the economy in Afghanistan, Iraq, Iran, and Pakistan brings advance political power of resilience to neoliberal ideology (see Excerpt 13 for example). States and its weapon industry has expanded in a complex model in the global projects of America to control so-called terrorism and cross border crimes as the novel describes the making and international exchange of weaponry relative to Islamic context "The Koran told of Daued, the raw youth with no weapons or armor who had used Jaloot's sword to slay him, Jaloot the giant whom the Christians call Goliath, having felled him with a sling first; and so the Afghans had used the captured the Soviet weapons as the instruments of the evil Godless empire's destruction...." (Aslam, 2008, p.78). And this divine method is seen through Casa, the omnipresent indigenous character reshaped by assaults of the neoliberal American empire as he states (see Except 14). Casa remains as a human beyond cultures, religions, races, and nationalities, beyond spatiotemporal boundaries. However, as a logistics being, his arguments about the deprivation of the Afghans by the draconian materialistic designs of the empires prevails the plot of the novel.

The ideology of free human, liberalism, or free economy is a utopia still unachieved in the Muslim nation-states. To address this "unsolved puzzle" (Lemm and Vatter, 2014, p, 5), I will begin to propose with Foucauldian perspective about the differentiation between classical and neoliberal nature of resilience or their shifts into changing shades. The emergence of classical liberalism is associated with the 18th-century political economy; trade or exchange is a free economic phenomenon between individuals (Smith, 1778, p.67). Smith explains the classical module as a specific methodology of state government "that can procure the nation's prosperity"(p.67). His vision of free economy inculcates a generalization of "the organization, distribution, and limitation of powers in a society" that sums up the market place as "site of the formation of truth" (Smith, 1776, p.25). Neoliberal ideology brought the flood of privatization, entrepreneurship and this expansion became a historical cause of conflict of humans as they promoted individual privatization. These Keynesian mechanisms contributed to the formulation of the individual's self-maximization that transmits collectiveness in society. Here, Smith offers a natural flow of market economy, he termed as invisible hands, which presents the idea that suggests that market functions through the competition based on the interests of the society and individuals. For Foucault, the metaphor of the invisible hands signals a profound transformation in the meaning and scope of sovereign power in a market with a free flow of exchange. It states that for the sovereign, it is approximately, impossible to have "any form of overarching gaze who would enable the economic process to be totalizedll (Foucault, 2010, p. 280,497). However, biopolitically settled neoliberal ideology functions as the reshaping force and an agency of conversion of social phenomenology into economization that converts the humans into global capitals, yet dogmatically, Stieglitz states (see in Excerpt 15). This biopolitically established 
international market creates a state of statelessness or deterritorialization for the biopower of nationstates after the wake of the war on terror on nation-states (Julian Reid, 2003, p. 57-85).

However, the strength of the neoliberal ideology also lies precisely in its capacity of its variable shade to adept and colonizes all spheres of social environments as Peck, Theodore, and Brenner (2010) highlight. Accordingly, they argue that the adaptable nature of neoliberalism makes or converts it into a project incomplete and partially socio-political system (see Excerpt 16). Consequently, neoliberalism does not present a separation from its theoretical frameworks to that of its opposing forces. This angle of neoliberalism ideology offers the reflection of its resilient capacity that ever has been changed, more adept, and has ever co-opted with differences often contending ideologies to conduct unification with social formalizations. The nature of convertibility turns it into an evasive target for opposite forces (Peck, Theodore, and Brenner, 2010, p.493). Similarly, Jamie Peck (2010, p. 106) points out how that neoliberalism Doxa has the power to change -from structural adjustment to good governance, from budget cuts to regulation-by-audit ... from privatization to public-private partnership, from greed-is-good to markets-with-morals" (p. 493) to prove that it is a resilient doxification. Accordingly, neoliberalism, promoted a culture of human capital (privatization) or homoeconomicus, where the market place has emerged as a self-organizing body of systems by having a capacity of reaching a balanced level of equilibrium, capable of touching the maximum point of collective interests of achieving an equilibrium that maximizes the individuals and collective interests of public and requires a limited state governmental watch. As in The Wasted Vigil, Casa becomes a man with an ideology of self-maximization in a newly democratic Muslim state. Thus, neoliberalism draws a line of clear demarcation between the sphere of politics, where the individuals are ruled as "subjects of rights" and the economic sphere, where they are governed as 'subjects of interests' (Foucault, 1778, p. 273-276). Moreover, in the vast scenario of globalization as David in The Wasted Vigil is an entrepreneur in gems and jeweler which he gets from the land of Afghanistan and he is a respondent of neoliberal doxifications in an everyday social reality. In the novel, Marcuse himself is a transnational capital who can move across the borders like the American military that controls the so-called crimes in the name of peace and transnational drug crimes. The self-oriented or self- satisfaction of the individuals creates a competition among the individual entrepreneurs or global entrepreneurs and a culture of creating more desires and demands of materialistic gains "I don't believe in ghosts though I believe in dollarized profit margins"(Hanif, 2018, p.168) and a desire of big business has created even among the simple indigenous population of Muslim nation-states. Red Bird (2018) paints the situation of the Muslim world where the Muslim population is at the mercy of a refugee camp The Hanger (Hanif, 2018, p. 170). Hanif has captured the very core of the transformation of the resilient feature of neoliberalism that has brought a materialistic change to the biopower, who wishes for a private business as Ali states (see Excerpt 17). This competition exists also among the states and nations to compete in the accumulation of wealth. The race of competition among states reaches to extreme when states dream of becoming global as Michael Hardt and Anton Negri (2000) puts in Empire. The empires loot the accumulation as Foucault states at the cost of "Zero-Sum" policy or poverty or misery. Moreover, America played the role of a global empire by destroying the states (Michael Hardt and Anton, Negri, 2000). In Red Birds, Momo cries over USA and USAID that first, the international powers come to bomb them and then send USAID and the mental health projects (Hanif, 2018, p.44). In this regard, the concept of human capital at the local base supports the empires to get them richer as Foucault suggests the technique of panoptical surveillance as represented in Excerpt 18. Thus, it brings humanity connected by going global dogmatically, creating divided selves, inequalities, and discomforts and disorders. These human capitals help to fetch the wealth of the Muslim nation sates as global competitors through big corporations as Ali dreams of a big project (see Excerpt 19).

Ali is a character who lives within the heart of the Muslim world metaphorically, representation of desert in the novel to show the neoliberal classic modernization and its functions of warfare as an economization of warfare of the world institutions. The global capital through trade intrusions, transport wealth to the rich states as the rich elites of the developing states as that of Pakistan, Afghanistan, and many Muslim states others. The protagonist of Red Birds sarcastically asks the teacher

- How do you build a supply chain?\| and then he answers the teacher as " I read in fortune 500 Annual that what makes a business great is not production, not distribution, not HR, but a great supply chain. 
Teacher was surprised." (Hanif, 2018, p.40) by pointing out the geographical importance of Afghanistan and the Middle East that how the Afghanistan has been a place of the supply for the transportation of the trades throughout in the history of global empires. As the diamond Koh-e-Noor now having net worth 12 Billion dollars was taken to India from Persia through Afghanistan by East India Company, the world first and largest corporation an example of free economy. David in The Wasted Vigil,1 a global capital is symbolic of rich Oriental history of the Muslims by that imperialists were hybridized. The world institutions established by the neoliberals' ideology as UNO, WBG, WOT, USAID, IMF, etc. all these global institutions play a vital role to maintain the dependency of the Muslim nation-states through these American established world institution which suck the blood of the poor population of the Muslim nation-states "they bombed us and then sent us welleducated people to look into our mental health needsl (Hanif,2018,p.44) through their socialist socalled structures of adjustments and pro-American projects of transnational so-called crime control designs and their post- trauma research projects that how they have transformed the cultural and economic values (see Excerpt 20).

Foucauldian panopticism accounts for the redistribution of controlling powers of the biopower through socially constructed institutions. These neoliberal institutions help or support the dependant states at the cost of tough conditions, is a result of that the every entrepreneur - long term prospects like I have done with Sand Globall (Hanif, 2018, p.20) as an individual of the developing states become a slave in the shape of a modern global capital where every soul is captive of neoliberal designs of global economic monetarism. In the novel The Wasted Vigil Mother Dear wants his son Ali to get a professional job of arms, in this job they assumed an opportunity to be rich, an appropriate global capital (see Excerpt 21) as in the panoptical economic progression, some individuals advance in life and the other locals "rank and file, view the progressives ones as they are at the same time a divide among locals who watched them as out of this world" (Baman, p.53- 54). The global capital is isolated and negligent of the miseries of the world; the echoes can be heard in The Wasted Vigil and Red Birds. The suffering locals contact with the global capitals via TV, satellite broadcasts, or on-air programs. The loud echoes ostentatiously reverberates glob wise, stifling all local sounds yet, reflected by their walls, whose self-prison-like impenetrable solidity is thereby reinforced and exhibited (Bauman,1998, p. 54). Similarly, Red Birds reveals the connectivity of internationalism with the locals as simple, traditional workers, however, are globally more connected with the international institutions as USAID or foreign stuff by living in the camp of refugees. It is itself a place of external connections where Momo dreams of making a factory of transistors as an entrepreneurial and wants to import guitar from Argentina as a global capital (Hanif, 2018, p.64). Paradoxically, these global capitals are projected beyond states, gain sovereign power of such citizens who render themselves "as investors or consumers, not as members of a democratic polity, who shares powers and certain common goods, spaces, and experiences\| (Brown, 2015, p.176). Accordingly, neoliberals, promote a society of the modern culture of individual humans as consumers at the local or global level. Consumerism as a political economy has evolved the socio-cultural nomads of the nation-states so that humans are individual consumers where an activism of involvement of the state that foster the process of economization and marketization in every sphere of - human activityll (Brown, 2015, Foucault, 2008) through politics of representation and simulacra. The neo techno western-style socialization has inflicted a state of inequality and instability as now, neoliberal resilient commercial culture creates first, desire, and then need for the consumers' demands, letting the discomfort go high. This social adaptability to the latest techno advancement (see Excerpt 22) has created new forms of consumerism that has brought such kind of social economization that only being a rich human can enjoy the consuming powers, cultivating a culture of money seekers and material seekers who can consume material products as the Red Birds reflects the transformation of the agrarian society into money wishers "The other half starts cursing each other's ancestors. Their sons keep going away and they keep waiting for them hoping they will return one-day bearing goody bags from a better world." (Hanif, 2018, p.27).

Relative Deprivation, the theory of inequality developed by Ted Robert Gurr, in Why Men Rebel, a classic magnum, in which Gurr took the idea of inequality and instability concept caused by neoliberal structural programs from W. G. Runciman, who in his turn, in Relative Deprivation and Social Justice has conducted a 1949 study of the U.S. military economization as privatization of the military institution, as the capital and discomfort that suggested discontent in comparisons to more 
successful reference groups(Inequality and Instability, p.2). Moreover, the Red Birds powerfully paints the extreme level of advanced human intrusions into the others' cultures to amaze the others as elites of the world as reflected in Excerpt 23. In the last few years, the voice for the inequalityinstability hypothesis has often come from neoclassical economists, most of the time. There was a time, all neoclassical economists went in favor of the thesis that internationally, income inequality is a functional result of the growth because "it raised the savings rate - rich people typically have a lower marginal propensity to consume than poor people - and therefore accelerated investment" (Rapley, 2004, p.3). However, Friedrich August Von Hayek (1899) in Road to Serfdom (1944), extended this claim further and its nuances that since demands for new improved products by the entrepreneurship almost always emerges from among the wealthy rich biopower, who alone can afford the cost embodied in advanced research and developmental projects of huge expenditures, socially as in Red Birds, Momo sheds light ironically on the project of research conducted by lady flower as; Teenage Muslim Mind and the impact on it of war as -PTSD\| but it cost heavily on the part of the state as first world useless projects - I am a survivor of the most useless war in the history of wars. Even our conquerors have abandoned us. What she has done for the country? Gone on a safari and spa holiday to Tanzania?\| (Hanif, 2018, p. 69) as she enjoys a luxurious life and the discomfort goes high and it happens at the cost of useless innovation that is also augmented by income inequality as 2016 report by the IMF - the most neoliberals organizations accepted that neoliberal policies have failed to tackle inequality\|l(Christine Schwobel-Patel, Neoliberalism: From Law to Resistance, 2019, p.3). Ali's father wants a job in the American military to get riches and, casa at the same time fighting against the receptions of globalization and its discontents created by the American forces.

Casa is transformed from a Jihadi to a skilled modern warrior who can make horrible forms of dangerous use of science and technology as under the result of contact with American- Afghan war operations ultimately, war itself is imposed on Muslim biopower as a result of free economy and its trans-border intrusions, a power of the neoliberal ideology of economization of even warfare and its privatizing contract companies in Afghanistan. Casa can make the destroying weapons from the natural element from the environment, as an imitation of American technology of destructive arms, a resilient form of capitalism to make the atomic bomb from the particles of the motherland that stands as a signifier of raping the land of the indigenous and original biopower "CYNIDE CAN BE EXTRACTED from apricots, Casa knows... a dangerous acid to be utilized in making of deadly weapons (Aslam, 2008, p.120). The power of resistance in casa is a signifier of the Muslim world at a large scale where (Wretched of the Earth) population may only find hope in foreign-funded private Madrassas, an arena - preconditioned for ISIS a resistive organization of the Muslim world, a state of savageryll where Casa enjoys a global movement as a (Raja, 2019, p.112).

In nation-states controlled by decentralized market networks, multinational corporations work as a neo elite international class of transnational capitalists, as stated in Atlantic Monthly, by Chrystia Freeland who focuses on "new plutocracy" as neo masters of nation-states (see Except 24). The power of the Muslim nation-states has also been gone in the hands of neoliberal ideology as in Wasted Vigil (2008) the feudal lords corporate, Nabi Khan and Gul Rasool get benefits from American and Russian led war, and become the warlords, fetch maximum profits. Here, in war, in Afghanistan benefits some few electives as horrible war political economy. A debate in Cambridge Review of International Affairs, recently, collected in a book: Marxism and New World Politics addresses "Putting the nation back into 'the international" by Scottish historian Neil Davidson (2012) who argues that the bifurcation "of the world into a system of competing nation-states is more than just a simple outgrowth of capitalism as a system of competing firms" (p.76). The dilemma of the Muslim nationstates is an influence by the western world of capitalism and industrialism (Harriott, 2004, p. 4) and it happens because of privatization to economization of the socialization. The World Bank, that monitors the transactions of money worldwide, the 1990s, had come to accept that adjustment programs had to do a fair system of delivering the developing states and should be assisting their transition to a new economy in a better way regardless of the influences of imperialism: "reconfiguration" rather than retreat has been the dominant trend. However, this debate sometimes fails to capture the meanings, is the profundity (Inequality and Instability, Rapley, p. 6).

The economization of the socialization is complex derive of the neoliberal expansion and an essential compositions of a stable regime, a perception of distributive equally served justice to the mass. This is not the same as equality. Distributive justice has historically been rooted in perceptions 
of not equal share, but just share. It becomes the cause of distributive economic injustice in the states of imperial influences as Andre Gunder Frank argues that the underdeveloped world can hardly be regarded as traditional since the capitalist system has "effectively and entirely penetrated even the most isolated sectors of the underdeveloped world." (The Development of Underdevelopment, 1974, p.26). This penetration, he suggests, has made the socioeconomic and even socio-cultural activities of the underdeveloped states miserably dependent upon the rich and developed nations because the majority of the Muslim-world comes under the dependency theory from where the equal-based inclusion of globalization is evidentially excluded. The dilemma of the results has been "a satellite development which [is] neither self-generating nor self-perpetuating." (Frank, 1974, p .47). He supports his thesis with a historical survey which indicates that the nation-states work as satellites and these satellites experience a mode of their greatest "economic development" especially, most classically a capitalist industrial advancement and development "if and when their ties to their metropolis are weakest."(Imperialism and Underdevelopment, A reader, edited by Robert I. Rhodes, p. 47). This dependency causes discomfort among the locals who are connected with the global capitalism and they suffer at the bottom level of the economization of the indigenous socialization, cultural, nomadic values and everyday life lived experience, the living reality in which the mass exists. The novels Red Bird and The Wasted Vigil portray an economization of the socialization as their resources; oil, sand, gold, diamonds etc; transform to the imperial metropolis.

The resilient power as high culture dominates the life patterns of the Muslim world and the population is catchy about the EuroAmerian dreams as Maulana Maudoodi (1903) concludes (see Excerpt 25). Both the novelist has evolved the plots of the stories as that the characters are fascinated by the neocolonial cultural suspensions amazingly. Similarly, Faiz Ahmed Faiz (1911) has described the two forms of culture (see Excerpt 26). From his segregation of culture into two forms, it is clear, that in the Muslim nation-states along with the culture medium, the cultural substance is lost or has loosened the collective thought, Muslim as one whole or perception of Ummah. The Muslim nationstates perceive the culture of individualism, by promoting nationalism influenced by Eurocentric liberal democracy. The regimes do not merely possess solid material social phenomena but at the same time it must possess unique a cultural and an original spiritual component as well to claim a valuable biopower with heuristic ethnic forms however, such components have lost place and a money accumulative, materialistic culture has taken the place. Hence, regime stability tends to correspond to cultural stability, and a regime crisis tends to correspond to cultural ferment and what Gramsci called hegemonic dissolution (Instability and Inequality, p.7). concerning the Muslim states and their biopowers, their studies of migration, cultural changes, the global-local homogenization, hyper differentiation nexus, the deterritorialization of culture, and the emergence of the global city, they have touched upon a reality of neoliberal resilience of which institutional decline or renewal is only a part, possibly no more than an epiphenomenon( p.7).

\section{Conclusion}

To sum up the paper, it is a conclusive stance of the conclusion that often biopolitics is perceived as an ideology that it is a state apparatus of guardianship and security of the biopower in Nation-states. However, Foucaultdian biopolitically established view is framed as an instrumental power to secure the population from the risks of neoliberalism that gives neoliberalism a slippery side towards adaptability and resiliencies. This power of biopolitics differentiates it from the resilient power of neoliberal ideology and its function of state rationality. Both the texts exhibit establishment of World Institutions and the deprived Muslim biopower who suffers from utter conditions of life through the hands of imperial representative and agent nation-states. However, the slipperiness of biopolitics has brought a historical change in the power shift, as Lara, Marcus, Casa, Momo, and Mother Dear, Zameen depict a strong voice against the established monarchies (Imperialists) and become a reason for the rise of the rest of the world or the suppressed, initiating a new chapter in global economic history, the termination of the American force from Afghanistan is an evident event of power shift.

Under biopolitical existing conditions, the conditions where the subjects; the biopower of the Asian Muslim nation-states is herded, as controlled shepherded by an advanced technological ideology of the new pastoral industrial or imperial controlling practices, has evoke a consciousness of self-governing among the mass. This biopolitical slipperiness is bringing a fresh air of deregulation, incentivization, and marketization so that the individuals can resist, conducting lives insufficiently 
pure entrepreneurial mode where man as an individual can interpret and respond to the everyday phenomena.

\section{References}

Ali, T. (2003). Bush in Babylon. Publ: Verso Books

Anthony, Harriott. (2000). Police and Crime Control in Jamaica. Kingston: University of the West Indies Press Arendt, H. (1789). The Perplexities of the Rights of Man: New York: Harcourt New York, London

Aslam, N. (2008). Wasted Vigil: London: Faber and Faber,

Agamben, G. (1998). Sovereign Power and Bare Life: Stanford University Press

Andre Gunder Frank. (2018). The Development of Underdevelopment: in S.C. Chew and R.A Denmark (eds) The underdevelopment of development: Essay in Honour of Andre Grande Frank, pp. 17-55, Thousand Oaks, CA: Sage.

Bauman, Z. (1893). Globalization the Human Consequence. Columbia: Columbia University Press Brown, W. (2015). Undoing the Demos: Neoliberalism's stealth revolution. New York: Zone Books. [Google Scholar]

Bablibar, E. (1991). Racism and Nationalism, in Race, Nation, Class: Ambiguous Identity. New York: New York Press

Campbell \& Adam Sitze. (2013). Right of Death and Power Over Life: Durham NC: Duke University Press

Christine, Schwobel-Patel. (2019). Neoliberalism: From Law to Resistance.

Crouch, C. (2011). The Strange Non-Death of neo-Liberalism. Cambridge: Polity

Foucault, M. (2008). The birth of biopolitics: Lectures at the Collège de France, 1978-79. Basingstoke: Palgrave Macmillan. [Crossref], [Google Scholar]

Faiz, A. Faiz. (2005). Culture and Identity: Oxford: Oxford University Press

Fraser, N. 2003. From Discipline to Flexibilization? Rereading Foucault in the Shadow of Globalization, Constellations, 10:2: 160-171.

Gray, J. (1995). Liberalism: Open University Press, 1995

Gurr. R, Ted. (1970). Why Men Rebel. Princeton: Princeton University Press

Harvey, D. (2010). The enigma of capital and the crises of capitalism. Oxford: Oxford University Press.

Hardt, M and Negri, A. (2000). Empire: Post-Marxist: Harvard University Press Hardt, M. \& Negri, A. (2009).Commonwealth. Boston, MA: Harvard University Press. Harvey, D. (2011). A Brief History of Neoliberalism: Oxford: Oxford University Press Hayek, F. A. (2006). The Road to Serfdom. Abingdon: Rutledge. [Google Scholar]

Julian, R. (2009). The Liberal Way of War: Killing to Make Life Live. Lapland: University of Lapland Julian Reid,(2003). Deleuze's War Machine: Nomadism Against The State: Millennium-Journal of International Studies: University of Lapland Press

Joseph, E. Stieglitz, (2002). Globalization and its Discontents: New York: Norton Press

Joseph, J. (2013). Resilience As Embedded Neoliberalism: A Governmentality Approach. Resilience. European Journal of International Relation, 2017, vol.23 (3)

Kelly, M. (2004). Racism, Nationalism and Biopolitics: Foucault's Society Must Be Defended, 2003, Contretemps, 4.2008. The Political Philosophy of Michel Foucault. New York: Routledge.

Kiersey, N. J. (2009).Scale, Security, and Political Economy: Debating the Biopolitics of the Global War on Terrors, New Political Science, 31:1: 27-47.

Konings, M. (2016). Governing the System: Risk, Finance, and Neoliberal Reason. European Journal of International Relations, 22(2)

Lemm, V \& Vatter M. (2014). The Government of Life: Foucault, Biopolitics, and Neoliberalism. Oxford: Oxford University Press

M. Lobo-Guerrero, L. (2008). Biopolitics of Security in the $21^{\text {st }}$ century: An introduction. Review of International Studies 34(2): New York: New York press

Mavelli, L.(2019).Resilience Beyond Neoliberalism? Mystique of Complexity Financial Crises, And The Reproduction Of Neoliberal Life. European Journal of International Relations.

Maudoodi, Abul, A. (1976). Human Rights in Islam: The Islamic Foundation, India

Peck, J, Theodore. N \& Brenner, N. (2010). Postneoliberalism and Its Malcontents. Antipode 41 (SI): 94-116.

Peck, J. (2010). Constructions of Neoliberal Reason: Oxford: OUP Oxford

Rapley, J. (2004). Globalization and inequality: Neoliberalism's Downward Spiral LYNNE RIENNER USA.

Robert I. Rhodes, (1971). Imperialism and Underdevelopment: A Reader: London, New York: Monthly Review Press

Raja, M. A, (2012). ISIS: Ideology, Symbolic, and Counter-Narratives: New York: Routledge Press Smith, A. (1776). An Inquiry into the Nature and Causes of the Wealth of Nations. (vol. 1) London: J.M. Dent and sons LT 